\title{
Effect of Solution pH on Layered Double Hydroxide Formation on Electrogalvanized Steel Sheets
}

\author{
Katsuya Hoshino $\mathbb{D}$, Shinichi Furuya, and Rudolph G. Buchheit
}

(Submitted September 18, 2018; in revised form February 22, 2019; published online March 7, 2019)

\begin{abstract}
The effect of solution pH on layered double hydroxide (LDH) formation on electrogalvanized steel sheets (EG steel) was investigated in this study. EG steel with a $\mathrm{Zn}$ coating weight of $64 \mathrm{~g} / \mathrm{m}^{2}$ was used as a substrate and was immersed in a $0.25 \mathrm{M} \mathrm{Na}_{2} \mathrm{Al}_{2} \mathrm{O}_{4}$-based solution having several $\mathrm{pH}$ values to form a $\mathrm{Zn}$ Al-based LDH conversion coating. After rinsing and drying, corrosion resistance was evaluated by EIS. It was found that corrosion resistance increased with increasing $\mathrm{pH}$ up to $\mathrm{pH}$ 12.6. However, above this $\mathrm{pH}$, corrosion resistance tended to display a sharp decrease. To understand this trend, the conversion coating was characterized by FT-IR, XRD and GDOES. The conversion coating was found to consist mainly of $\mathrm{Zn}_{2} \mathrm{Al}(\mathrm{OH})_{6}\left(\mathrm{CO}_{3}\right)_{0.5} \cdot \mathrm{xH}_{2} \mathrm{O}$ crystals (an $\left.\mathrm{LDH}\right)$. The thickness of the conversion coating layer increased with increasing $\mathrm{pH}$ up to $\mathrm{pH}$ 12.4, but above this $\mathrm{pH}$, its thickness tended to decrease due to the formation of $\mathrm{ZnO}$. The reason for the dependence of corrosion resistance on solution $\mathrm{pH}$ is discussed from the viewpoints of the thickness and changes in the microstructure of the conversion coating layer, including its crystal size, density and uniformity, which could vary during the initial formation of $\mathrm{ZnO}$ at $\mathrm{pH}$ values above 12.6.
\end{abstract}

Keywords conversion coating, corrosion resistance, galvanized steel, layered double hydroxide

\section{Introduction}

Layered double hydroxides (LDHs) are chemical compounds with the general formula $\mathrm{M}_{(1-\mathrm{X})}^{2+} \mathrm{M}_{\mathrm{X}}^{3+}(\mathrm{OH})_{2}\left(\mathrm{~A}^{\mathrm{n}-}\right)_{\mathrm{X} / \mathrm{n}}$. $\mathrm{mH}_{2} \mathrm{O}$, where $\mathrm{M}^{2+}$ is a divalent cation, $\mathrm{M}^{3+}$ is a trivalent cation and $\mathrm{A}^{\mathrm{n}-}$ is an anion. $\mathrm{LDH}$ compounds have layered crystal structures consisting of a mixed $\mathrm{M}^{2+} / \mathrm{M}^{3+}$ hydroxide layer separated by a layer containing hydrated anions, $\mathrm{A}^{\mathrm{n}-}$. Among other cations, $\mathrm{Zn}^{2+}$ and $\mathrm{Mg}^{2+}$ are common for $\mathrm{M}^{2+}$ and $\mathrm{Al}^{3+}$ is common for $\mathrm{M}^{3+}$. It is well known that the interlayer anions are exchangeable with anions present in a surrounding solution or corrosion environment.

This anion exchange is the basis for the storage-and-release inhibitor concept that underlies LDH-based corrosion-inhibiting pigments. The effects of addition of LDH-based pigments to organic coatings on corrosion resistance have been widely investigated. R. G. Buchheit and S. P. V. Mahajanam et al. reported that $\left[\mathrm{V}_{10} \mathrm{O}_{28}\right]^{6-}$-intercalated $\mathrm{Zn}$-Al-based LDHs added to an organic coating layer improve the corrosion resistance of an Al alloy substrate (Ref 1-4). They also demonstrated that the $\left[\mathrm{V}_{10} \mathrm{O}_{28}\right]^{6-}$ anions were released from the LDHs during

\footnotetext{
Katsuya Hoshino, Fontana Corrosion Center, Department of Materials Science and Engineering, College of Engineering, The Ohio State University, 2041 N. College Rd, Columbus, $\mathrm{OH}$ 43210; and Steel Research Laboratory, JFE Steel Corporation, 1 Kokan-cho, Fukuyama, Hiroshima 721-8510, Japan; Shinichi Furuya, Steel Research Laboratory, JFE Steel Corporation, 1 Kokan-cho, Fukuyama, Hiroshima 721-8510, Japan; and Rudolph G. Buchheit, Department of Chemical and Materials Engineering, University of Kentucky, Lexington, KY 40506. Contact e-mails: k-hoshino@jfe-steel.co.jp, s-furuya@jfe-steel.co.jp and Rudolph.Buchheit@uky.edu.
}

exchange with $\mathrm{Cl}^{-}$anions found in the surrounding $\mathrm{Cl}^{-}$-rich corrosion environment (Ref 1-4). G. Williams and H.N. McMurry showed that the addition of $\mathrm{CO}_{3}{ }^{2-}, \mathrm{NO}_{3}{ }^{-}$or $\mathrm{CrO}_{4}{ }^{2-}$-containing $\mathrm{Mg}$-Al-based LDHs to organic coatings improves filiform corrosion resistance on $\mathrm{Al}$ alloy substrates (Ref 5-10). These coatings have also been applied to other materials such as galvanized steel sheets and cold-rolled mild steel sheets with promising results (Ref 11-14).

Because the LDH compounds can be produced easily by hydrothermal synthesis, LDH-based conversion coatings produced by simple immersion processes are also possible. These easily produced coatings have been applied on Al alloys and galvanized steel. For example, it was previously shown that a corrosion-resistant $\mathrm{Li}-\mathrm{Al}-\mathrm{CO}_{3} \mathrm{LDH}$ coating will form on $\mathrm{Al}$ alloy substrates by simple immersion of the substrate in a lithium carbonate solution (Ref 15-18). It has also been shown that a corrosion-resistant $\mathrm{Zn}$-Al-based LDH coating forms on hot-dip galvanized steel sheets by immersion of the sheets in a high alkaline sodium aluminate solution (Ref 19). However, the mechanisms of LDH formation and corrosion protection by a LDH conversion coating layer on galvanized steel have not been thoroughly investigated, and the formed LDH conversion coating layers have not yet been fully characterized.

This study seeks to understand the LDH formation mechanism and corrosion protection provided by a conversioncoated Zn-Al-based LDH layer on galvanized steel, the effect of solution $\mathrm{pH}$ on $\mathrm{LDH}$ formation on electrogalvanized steel (EG steel) and the associated corrosion resistance.

\section{Experimental Procedure}

\subsection{Test Specimens and Treatment Procedures}

The test samples were 0.75 -mm-thick electrogalvanized mild steel sheets. The coating weight of $\mathrm{Zn}$ on the evaluated side of the test specimens was $64 \mathrm{~g} / \mathrm{m}^{2}$. All the specimens were 
provided by JFE Steel Corporation. The specimens were cut to $50 \mathrm{~mm} \times 70 \mathrm{~mm}$ and degreased with ethanol before treatment.

In order to form the $\mathrm{LDH}$ conversion coating layer, $\mathrm{Na}_{2} \mathrm{Al}_{2} \mathrm{O}_{4}$ solutions containing $0.1 \mathrm{M} \mathrm{KNO}_{3}, 0.01 \mathrm{M} \mathrm{NH}_{4} \mathrm{NO}_{3}$ and $0.01 \mathrm{M} \mathrm{Zn}\left(\mathrm{NO}_{3}\right)_{2} \cdot 6 \mathrm{H}_{2} \mathrm{O}$ were prepared. The concentration of $\mathrm{Na}_{2} \mathrm{Al}_{2} \mathrm{O}_{4}$ was varied from 0.050 to $0.250 \mathrm{M}$. Stirred solutions were aged for various time periods (120 to $480 \mathrm{~min}$ ), after which the test specimens were immersed in each solution for $16 \mathrm{~h}$ at room temperature without stirring. The $\mathrm{pH}$ of the treatment solutions varied in the range of 11.5 to 13.3 depending on the concentration of $\mathrm{Na}_{2} \mathrm{Al}_{2} \mathrm{O}_{4}$ and aging time. The parameters for each of the solutions are summarized in Table 1. It is known that the precipitation of aluminum hydroxide can occur in $\mathrm{Na}_{2} \mathrm{Al}_{2} \mathrm{O}_{4}$ solution which contains $\mathrm{CO}_{2}$ (Ref 20). This could cause the change of the solution $\mathrm{pH}$ depending on the aging time in this study, because $\mathrm{CO}_{2}$ can dissolve in it from air. The $\mathrm{pH}$ of the treatment solution No. 9 condition was controlled with addition of $1.0 \mathrm{M} \mathrm{NaOH}$ solution to investigate the influence of solution $\mathrm{pH}$ without changing the concentration of $\mathrm{Na}_{2} \mathrm{Al}_{2} \mathrm{O}_{4}$ and aging time. After rinsing with deionized water and air drying, the corrosion resistance of each specimen was evaluated and the coating layers were characterized.

\subsection{Evaluation of Corrosion Resistance}

The corrosion resistance of the coated specimens was evaluated by electrochemical impedance spectroscopy (EIS). Measurements were carried out in a $0.1 \mathrm{M} \mathrm{NaCl}$ solution after immersion for $1 \mathrm{~h}$ at room temperature. A sinusoidal $10 \mathrm{mV}$ voltage signal was used as the perturbation with frequencies ranging from 10,000 to $0.01 \mathrm{~Hz}$. To evaluate corrosion resistance, impedance at $0.01 \mathrm{~Hz}$ was compared, which was demonstrated at the lowest measured frequencies.

\subsection{Analyses of Coating Layer}

The following surface observations and analyses were carried out in order to determine the interlayer anions, crystal structure, microstructure, appearance and chemical compositions of the resulting LDH conversion coating layers.

Fourier-transform infrared spectroscopy (FT-IR) spectra were obtained with a FT-IR spectrometer (WINSPEC-100, JEOL). The measurements were carried out by reflection absorption spectroscopy with a $75^{\circ}$ incident angle and 100 accumulations.
X-ray diffraction (XRD) patterns of the coating layer were determined with an X-ray diffractometer (SmartLab, Rigaku). The incident angle was $3^{\circ}$. The radiation source was a $\mathrm{Cu} \mathrm{K} \alpha$ target. A scan range of $5^{\circ}$ to $45^{\circ}$ was employed with a scan speed and step of $10^{\circ} / \mathrm{min}$ and $0.01^{\circ}$, respectively. The tube voltage and tube current were $45 \mathrm{kV}$ and $44 \mathrm{~mA}$, respectively.

The depth profile of the coating layer was determined by glow discharge optical emission spectrometry (GDOES) (GDProfiler 2, HORIBA). Ar plasma was used for sputtering with an Ar pressure of $600 \mathrm{~Pa}$. Power of $35 \mathrm{~W}$, a sampling time of $10 \mathrm{~ms}$ and an Ar flushing time of $30 \mathrm{~s}$ were employed. The measured area was circular with a $4 \mathrm{~mm}$ diameter. The sputtering rate under these conditions was determined as approximately $60 \mathrm{~nm} / \mathrm{sec}$ for mild steel sheets by a measured actual depth of the sputtered area with a 3D microscope and sputtering time.

The surface of the coating layer was observed with a scanning electron microscope (SEM) (JSM-6060, JEOL) equipped with a secondary electron (SE) detector. The acceleration voltage during observation was $5 \mathrm{kV}$.

Cross sections of the coating layer were observed with an SEM (ULTRA PLUS, Carl Zeiss) and analyzed by energydispersive X-ray spectrometry (EDX), which was incorporated in the SEM. The instrument was equipped with a backscattered electron (BSE) detector. The acceleration voltages employed during observation and analysis were 1 and $5 \mathrm{kV}$, respectively. $45^{\circ}$ cross-sectional specimens were prepared with a focused ion beam (FIB) instrument (Quanta 200 3D, FEI) for SEM observations.

\section{Results}

\subsection{Corrosion Resistance}

The Nyquist plots from the EIS analysis of the LDH-treated specimens subjected to the solutions of various $\mathrm{pH}$ values are shown in Fig. 1. Because the spectra were complex, Fig. 2 shows the impedance at $0.01 \mathrm{~Hz}$ as a function of solution $\mathrm{pH}$. The impedance clearly increased with increasing $\mathrm{pH}$ of the treatment solution up to a maximum value at $\mathrm{pH}$ 12.6. Above this $\mathrm{pH}$, impedance decreased dramatically. These results suggest that corrosion resistance is dependent on the $\mathrm{pH}$ of the treatment solution, with optimal results obtained from a treatment solution with a $\mathrm{pH}$ of 12.6. The measurement of

Table 1 Conditions of treatment solutions used

\begin{tabular}{|c|c|c|c|c|c|c|}
\hline \multirow[b]{2}{*}{ No. } & \multicolumn{4}{|c|}{ Concentration (M) } & \multirow[b]{2}{*}{ Aging time, m } & \multirow[b]{2}{*}{$\mathbf{p H}$} \\
\hline & $\mathrm{Na}_{2} \mathrm{Al}_{2} \mathrm{O}_{4}$ & $\mathrm{Zn}\left(\mathrm{NO}_{3}\right)_{2} \cdot 6 \mathrm{H}_{2} \mathrm{O}$ & $\mathbf{N H}_{4} \mathrm{NO}_{3}$ & $\mathrm{KNO}_{3}$ & & \\
\hline 1 & 0.05 & 0.01 & 0.01 & 0.10 & 120 & 11.5 \\
\hline 2 & 0.13 & 0.01 & 0.01 & 0.10 & 120 & 12.0 \\
\hline 3 & 0.15 & 0.01 & 0.01 & 0.10 & 120 & 12.3 \\
\hline 4 & 0.20 & 0.01 & 0.01 & 0.10 & 120 & 12.4 \\
\hline 5 & 0.25 & 0.01 & 0.01 & 0.10 & 120 & 12.6 \\
\hline 6 & 0.25 & 0.01 & 0.01 & 0.10 & 180 & 12.7 \\
\hline 7 & 0.25 & 0.01 & 0.01 & 0.10 & 240 & 12.9 \\
\hline 8 & 0.25 & 0.01 & 0.01 & 0.10 & 480 & 13.2 \\
\hline 9 & 0.25 & 0.01 & 0.01 & 0.10 & 120 & 13.3 \\
\hline
\end{tabular}




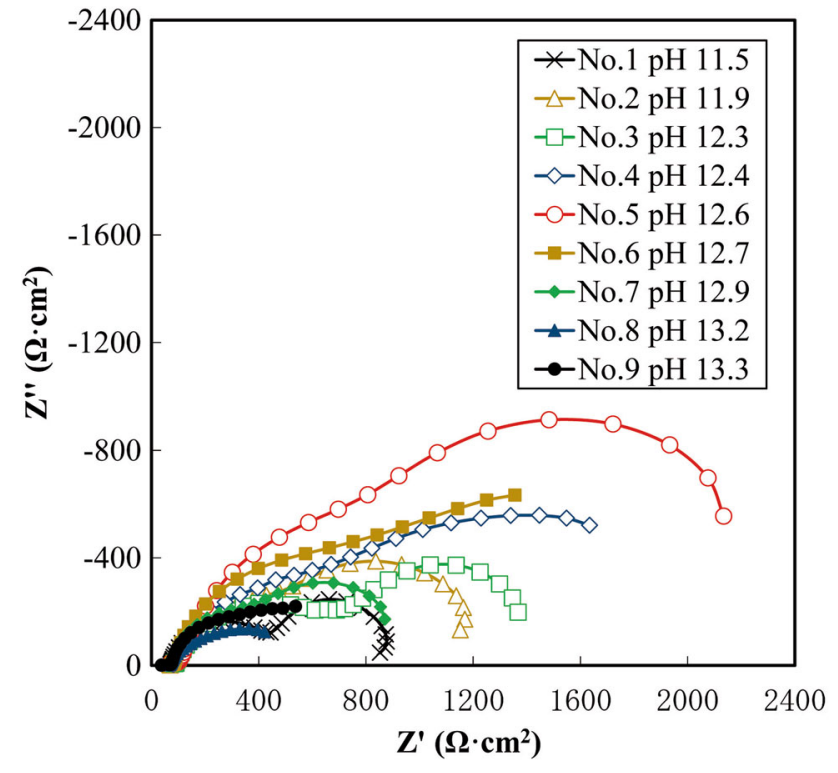

Fig. 1 Evolution of EIS spectra for LDH-treated specimens during exposure to $0.1 \mathrm{M} \mathrm{NaCl}$ solution. $\mathrm{pH}$ refers to the treatment solution conditions

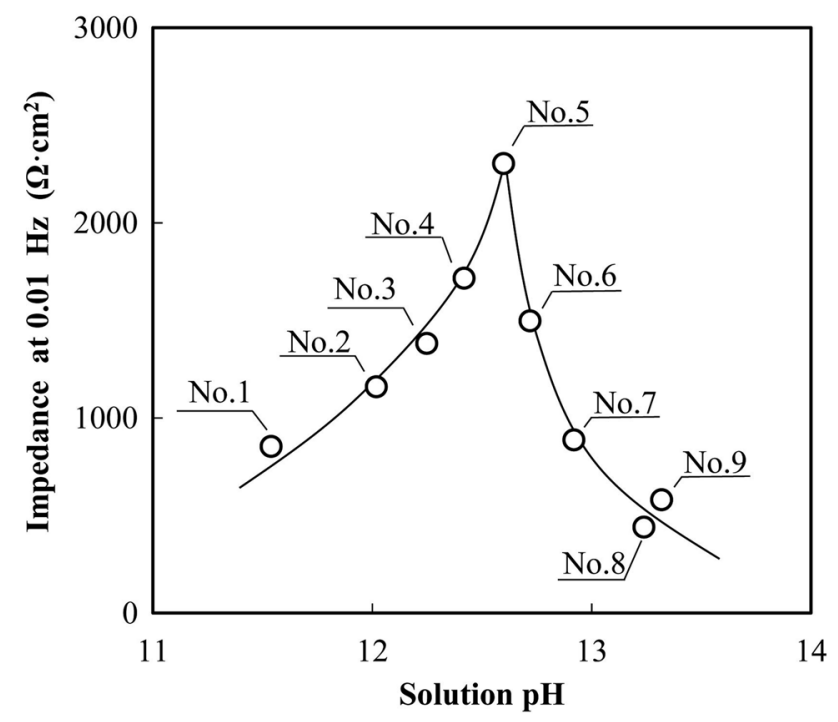

Fig. 2 Relationship between impedance at $0.01 \mathrm{~Hz}$ and solution $\mathrm{pH}$. Designated numbers in the figure correspond to the treatment solution number (Table 1)

impedance of the specimens treated with the treatment solution No. 5 condition (Table 1) was repeated three times. The average value and standard deviation were 2071 and 262 $\Omega \mathrm{cm}^{2}$, respectively.

\subsection{Analysis of Coating Layer}

The FT-IR spectrum of an LDH-treated specimen produced under the treatment solution No. 5 condition (Table 1) is shown in Fig. 3. Peaks were observed at 461, 573, 874, 1365, 3296 and $3861 \mathrm{~cm}^{-1}$. These peaks display reasonable agreement with the FT-IR spectra of solid $\mathrm{Zn}_{\mathrm{x}} \mathrm{Al}_{1-\mathrm{x}}\left(\mathrm{CO}_{3}\right)_{2 / \mathrm{x}}(\mathrm{OH})_{2} \cdot \mathrm{nH}_{2} \mathrm{O}$ (Ref 21). Analysis of all the test specimens resulted in similar spectra, suggesting that $\mathrm{Zn}_{\mathrm{x}} \mathrm{Al}_{1-\mathrm{x}}\left(\mathrm{CO}_{3}\right)_{2 / \mathrm{x}}(\mathrm{OH})_{2} \cdot \mathrm{nH}_{2} \mathrm{O}$ was

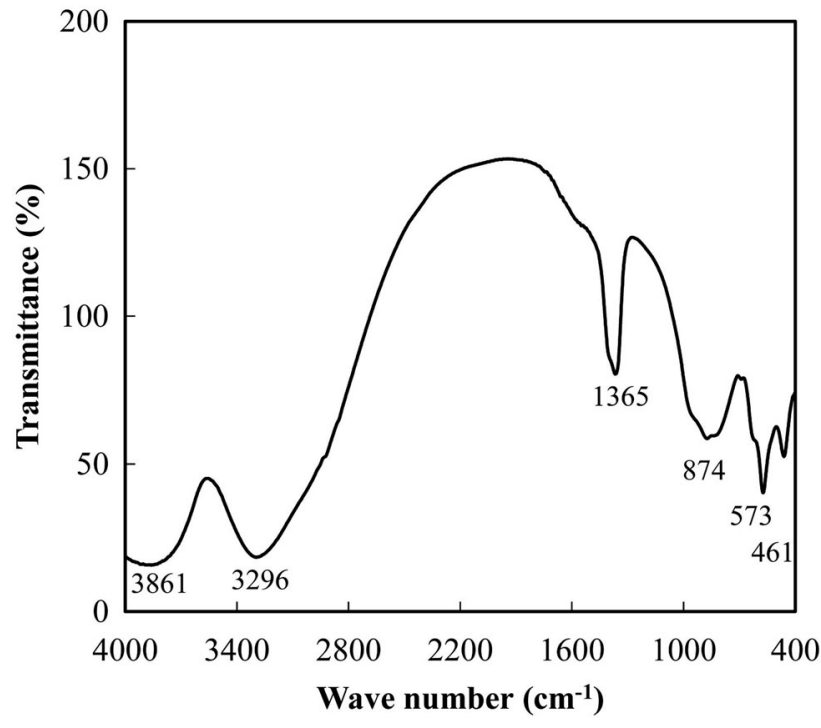

Fig. 3 FT-IR spectrum of LDH-treated specimens produced under No. 5 treatment solution condition

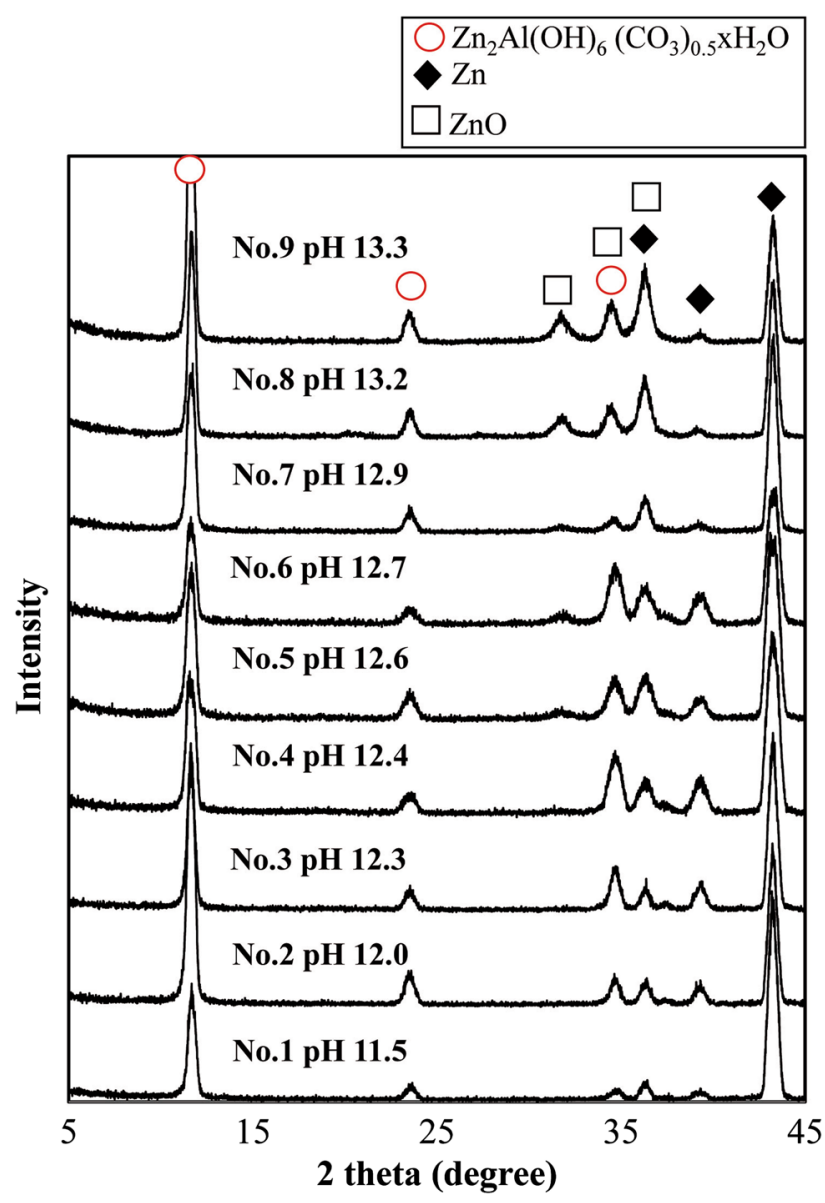

Fig. 4 XRD patterns of LDH-treated specimens. pH refers to the treatment solution conditions

successfully formed on the EG steel samples. $\mathrm{Zn}_{\mathrm{x}} \mathrm{Al}_{1-\mathrm{x}}\left(\mathrm{CO}_{3}\right)_{2 /}$ ${ }_{x}(\mathrm{OH})_{2} \cdot \mathrm{nH}_{2} \mathrm{O}$, an $\mathrm{LDH}$, is comprised of the basic layers of a mixed $\mathrm{Zn}^{2+}$ and $\mathrm{Al}^{3+}$ hydroxide and a $\mathrm{CO}_{3}{ }^{2-}$ and $\mathrm{H}_{2} \mathrm{O}$ interlayer. 


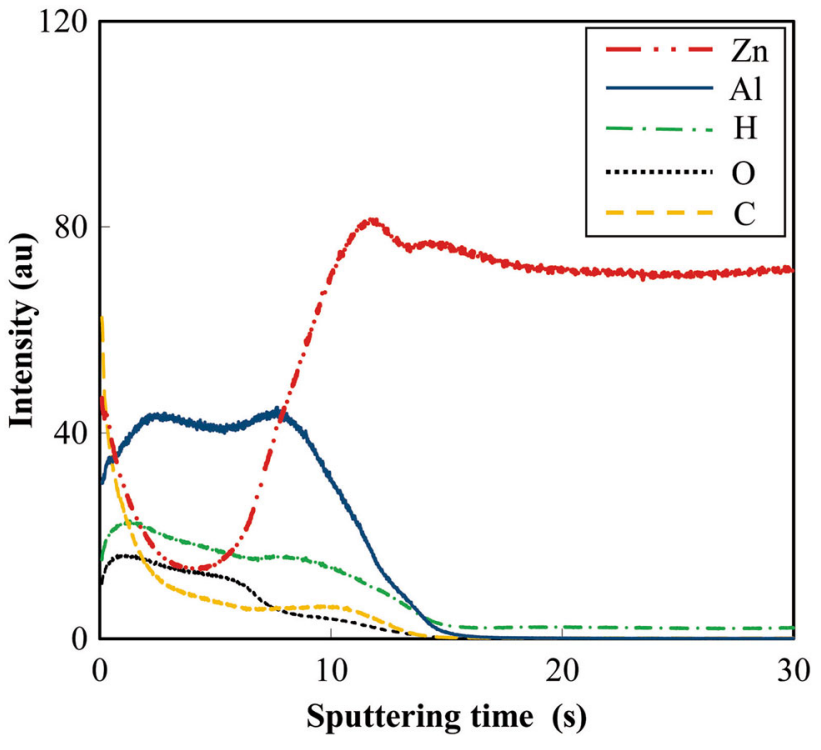

Fig. 5 Depth profile of LDH-treated specimens produced under No. 5 treatment solution condition analyzed by GDOES

The XRD spectra acquired from the specimens after LDH conversion coating are shown in Fig. 4. The spectrum of each specimen displays clear evidence of the presence of a $\mathrm{Zn}$ substrate [PDF Card No.: 01-078-9363] and of $\mathrm{Zn}_{2} \mathrm{Al}(\mathrm{OH})_{6}$ $\left(\mathrm{CO}_{3}\right)_{0.5} \times \mathrm{xH}_{2} \mathrm{O}$ (Zn-Al-CO $\mathrm{CO}_{3}$ LDH) [PDF Card No.: 00-0481023]. These results also support the above-mentioned results that the LDH conversion coating was successfully applied to the EG steel samples and the conversion coating layer consisted mainly of $\mathrm{Zn}-\mathrm{Al}-\mathrm{CO}_{3} \mathrm{LDH}$. Based on the XRD results, although the layer consists of only $\mathrm{Zn}-\mathrm{Al}-\mathrm{CO}_{3} \mathrm{LDH}$ below $\mathrm{pH}$ 12.6, diffraction patterns of $\mathrm{ZnO}$ [PDF Card No.: 01-0708072] were also observed above $\mathrm{pH}$ 12.6. This indicates that the composition of the layer changes near $\mathrm{pH}$ 12.6. This accords well with the decrease in corrosion resistance observed at $\mathrm{pH} 12.6$ in the EIS experiments (Fig. 2).

A representative GDOES depth profile of an LDH-treated specimen produced under the No. 5 treatment solution condition is shown in Fig. 5. $\mathrm{Zn}, \mathrm{Al}, \mathrm{O}, \mathrm{C}$ and $\mathrm{H}$ were all detected on the surface of the specimens. This result also supports the conclusion that the $\mathrm{Zn}-\mathrm{Al}-\mathrm{CO}_{3} \mathrm{LDH}$ conversion coating was successfully formed. It can be said that the thickness of the $\mathrm{Zn}$ $\mathrm{Al}-\mathrm{CO}_{3} \mathrm{LDH}$ correlates with the amount of $\mathrm{Al}$ because $\mathrm{Al}$ is one of the composition of the LDH layer and other layers do not contain Al. The amount of $\mathrm{Al}$ can be estimated from integration of $\mathrm{Al}$ intensity of GDOES profiles. Integrated $\mathrm{Al}$ intensity was obtained by integration of net Al intensity of GDOES profiles, when balk Al intensity was defined as background, with sputtering time. Figure 6 shows the integrated $\mathrm{Al}$ intensity as a function of the $\mathrm{pH}$ of the treatment solution. The integrated $\mathrm{Al}$ intensity increased as the solution $\mathrm{pH}$ increased up to $\mathrm{pH} 12.4$, and above this $\mathrm{pH}$, the integrated $\mathrm{Al}$ intensity tended to decrease. This suggests that the thickness of the coating layer increased as the solution $\mathrm{pH}$ increased up to

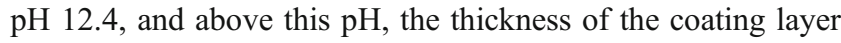
tended to decrease.

In the conversion coating reaction, $\mathrm{Zn}$ could be provided by the dissolution reaction of the $\mathrm{Zn}$ substrate in addition to the aqueous $\mathrm{Zn}\left(\mathrm{NO}_{3}\right)_{2}$ in the treatment solution. Therefore, the increase in the conversion coating layer thickness observed

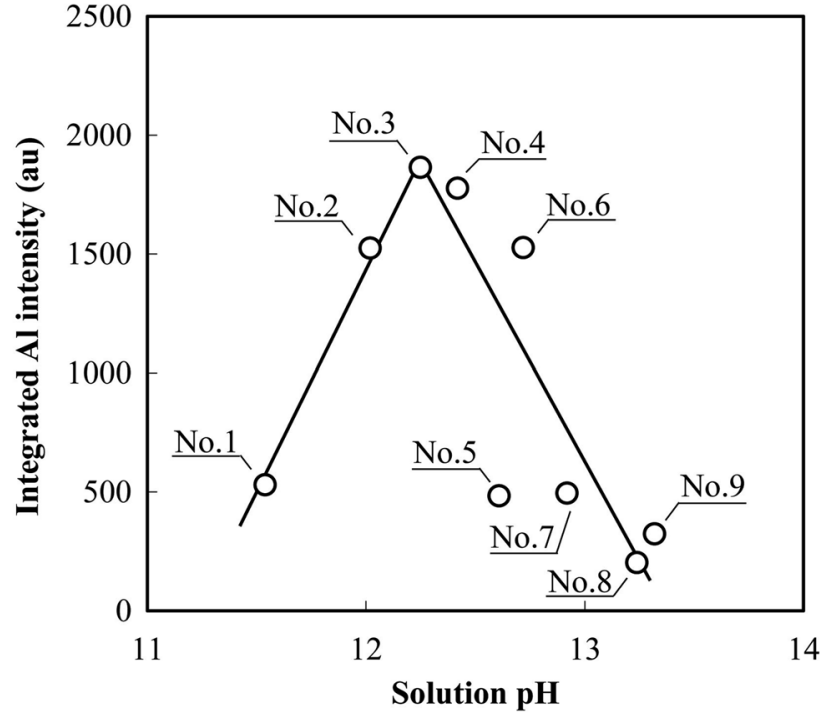

Fig. 6 Relationship between integrated Al intensity obtained with GDOES and $\mathrm{pH}$ of treatment solution. Designated numbers in the figure correspond to the treatment solution number (Table 1)

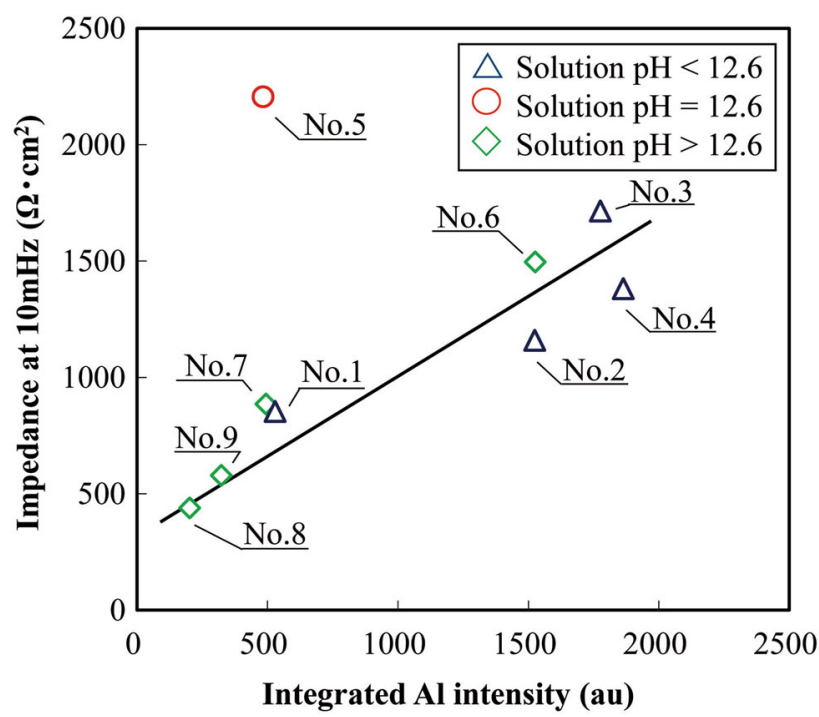

Fig. 7 Relationship between impedance at $0.01 \mathrm{~Hz}$ and integrated Al intensity obtained with GDOES. Designated numbers in the figure correspond to the treatment solution number (Table 1)

with increasing $\mathrm{pH}$ could be attributed to the dissolution rate of the $\mathrm{Zn}$ substrate, which would be accelerated with increasing $\mathrm{pH}$. However, the solubility of $\mathrm{Zn}$ and $\mathrm{Al}$ also increases with increasing $\mathrm{pH}$, which would explain why the conversion coating layer thickness decreased with increasing $\mathrm{pH}$ above this $\mathrm{pH}$ value.

\section{Discussion}

\subsection{Effect of Conversion Coating Layer Thickness on Corrosion Resistance}

The similarity between the trends of impedance (Fig. 2) and the integrated $\mathrm{Al}$ intensity (Fig. 6) as a function of solution $\mathrm{pH}$ 
(a) No.2 $\mathrm{pH} 12.0$

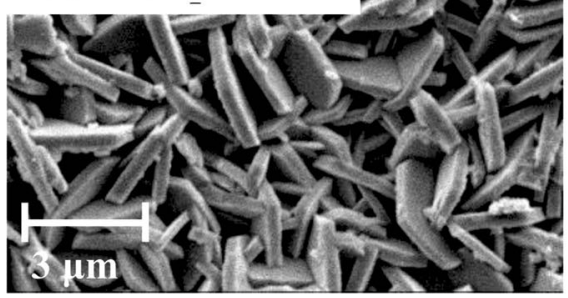

(d) $\quad$ No.5 pH 12.6

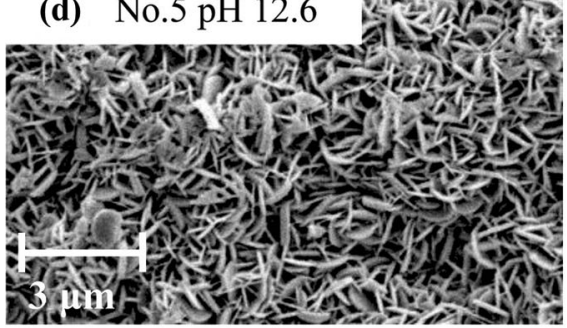

(b) No.3 $\mathrm{pH} 12.3$

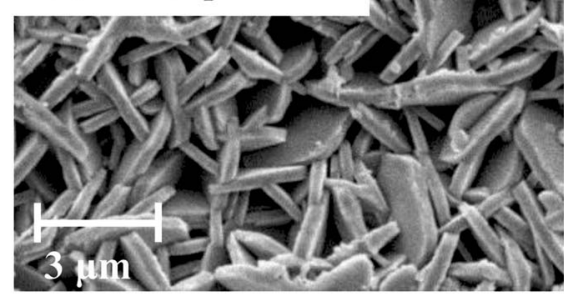

(e) $\quad$ No.8 $\mathrm{pH} 12.9$

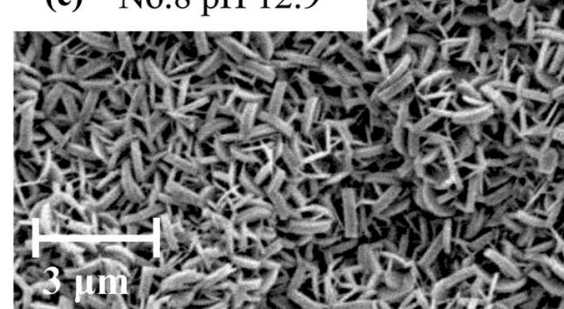

(c) $\quad$ No.4 pH 12.4
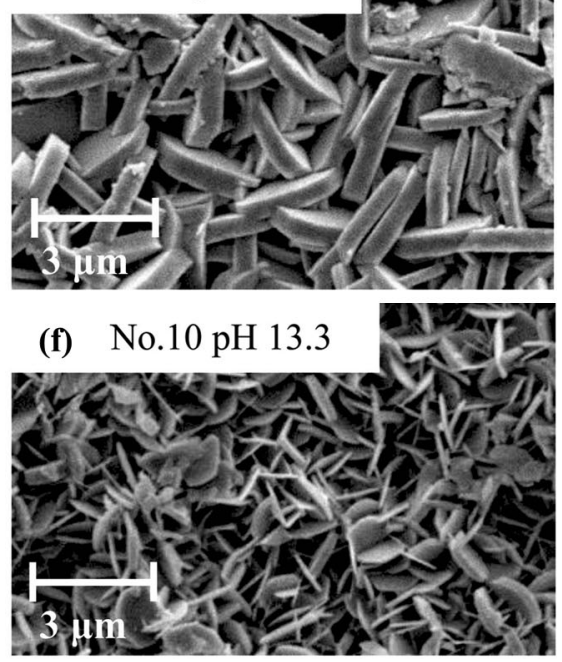

Fig. 8 SEM images of LDH-coated specimens. $\mathrm{pH}$ refers to the treatment solution conditions
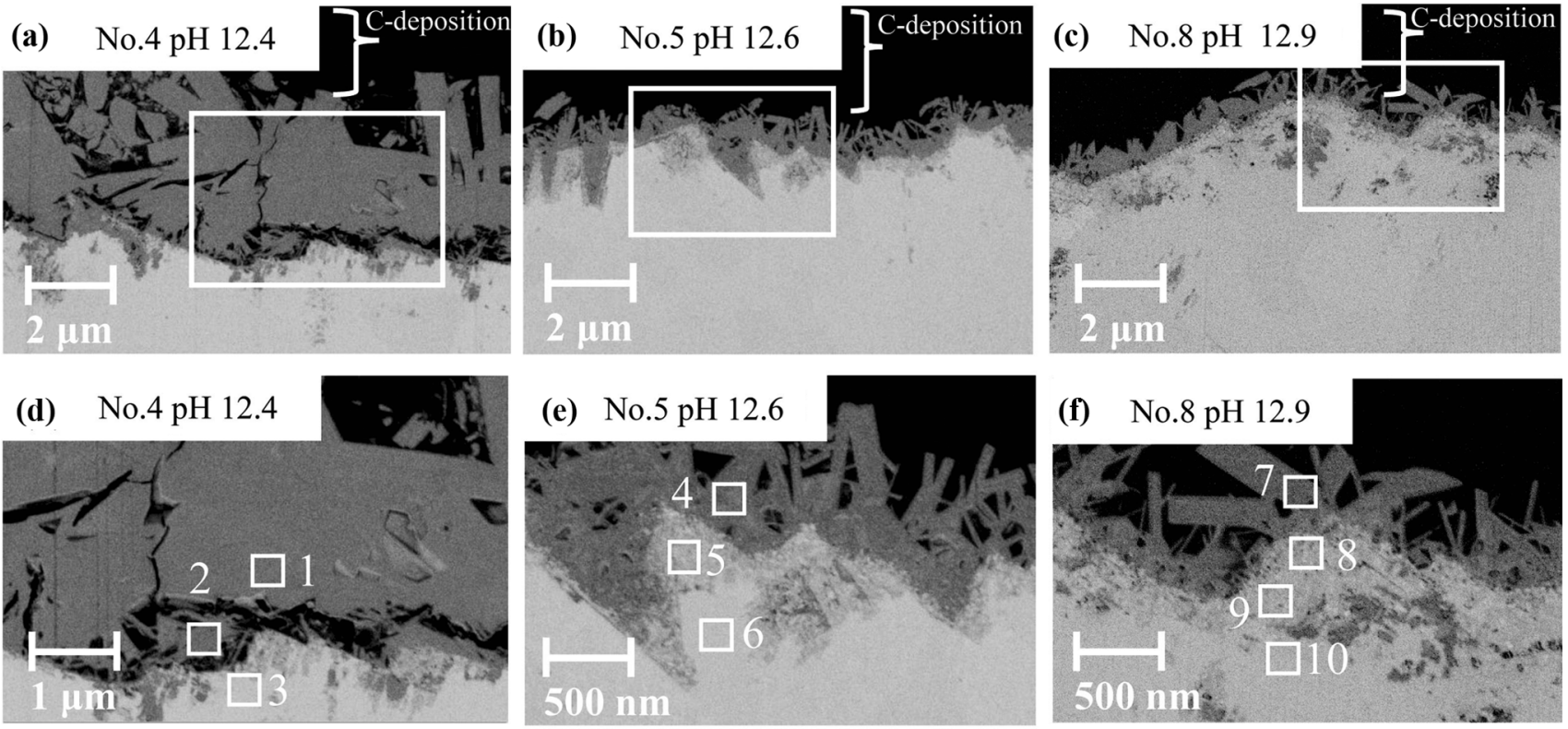

Fig. 9 Cross-sectional SEM images of LDH-coated specimens. The white boxes in (a-c) were observed at high magnification and (d-f) show the results, respectively

suggest that the conversion coating layer thickness might affect corrosion. The data provided in Fig. 7 further support this relationship. Essentially, impedance tended to increase as the integrated $\mathrm{Al}$ intensity increased. This suggests an increase in corrosion resistance with increasing conversion coating layer thickness. However, at $\mathrm{pH}$ 12.6, higher impedance was observed even with a thinner coating layer. This suggests that corrosion resistance cannot be explained solely by the coating layer thickness.

\subsection{Effect of Solution pH on Microstructure of Coating Layer}

In order to understand how the conversion coating layer affects corrosion resistance, SEM images of the surface of the treated specimens are shown in Fig. 8. Platelike crystals, typical of the shape of LDH crystals, cover the surface after treatment at all $\mathrm{pH}$ values. The crystal size, however, tended to increase slightly as the $\mathrm{pH}$ was increased from $\mathrm{pH} 12.0$ to $\mathrm{pH} 12.4$, but above $\mathrm{pH} 12.6$, the crystals showed a marked decrease to finer sizes.

The $45^{\circ}$ cross sections of three test specimens prepared in solutions at $\mathrm{pH}$ 12.4, 12.6 and 12.9 were obtained using FIB. The BSE images of these specimens are shown in Fig. 9. In this $\mathrm{pH}$ region, as with the GDOES data, an increase in $\mathrm{pH}$ tended to lead to a thinner conversion coating layer. Although a thicker conversion coating layer was observed at $\mathrm{pH} 12.4$, some cracks and crevices were also observed. At the $\mathrm{pH}$ values of 12.6 and 12.9 , the conversion coating layer appeared denser and more 
Table 2 Analytical results of EDX of areas in white boxes (1-10) in Fig. 9 (d)-(f)

\begin{tabular}{lrrrr}
\hline & \multicolumn{4}{c}{ Composition at. \% } \\
\cline { 2 - 5 } Analyzed area & Al & Zn & O & C \\
\hline 1 & 15 & 35 & 46 & 3 \\
2 & 11 & 41 & 43 & 5 \\
3 & 0 & 95 & 2 & 2 \\
4 & 13 & 37 & 48 & 4 \\
5 & 1 & 59 & 39 & 2 \\
6 & 0 & 96 & 2 & 2 \\
7 & 13 & 34 & 47 & 6 \\
8 & 1 & 51 & 55 & 2 \\
9 & 0 & 54 & 44 & 2 \\
10 & 0 & 95 & 3 & 3 \\
\hline
\end{tabular}

(a)

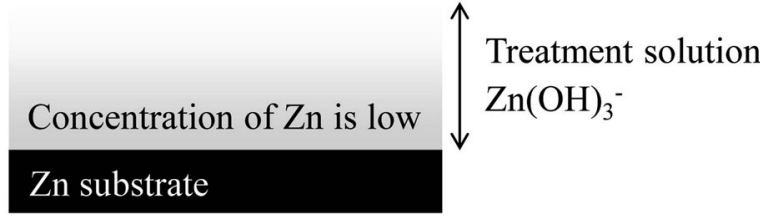

(b)

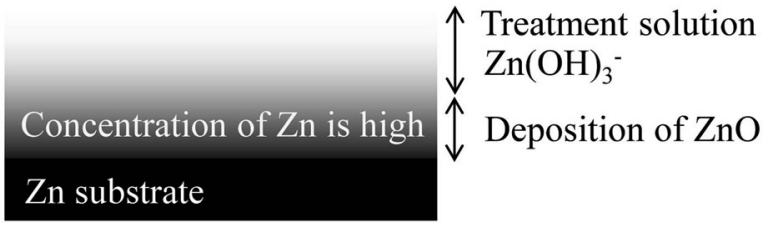

Fig. 10 Schematic images of interface between $\mathrm{Zn}$ substrate and treatment. (a) Lower solution $\mathrm{pH}$ and (b) higher solution $\mathrm{pH}$

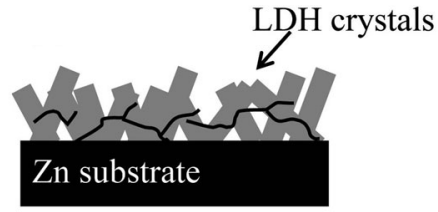

(a)

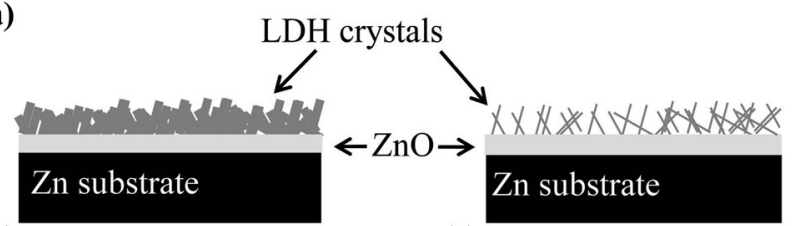

(b)

(c)

Fig. 11 Cross-sectional schematic images of microstructure of LDH layer depending on solution $\mathrm{pH}$. (a) $\mathrm{pH}<12.6$, (b) $\mathrm{pH}=12.6$ and (c) $\mathrm{pH}>12.6$

uniform than that of the specimens prepared at $\mathrm{pH} 12.4$, and there was also an absence of cracks and crevices. As mentioned above, the crystal size changed drastically around $\mathrm{pH}$ 12.6. This could affect whether cracks and crevices were observed or not because larger crystals induce strain and distortion which cause cracks and crevices in coating layer. In addition to the difference, an area of medium brightness was observed in the lower conversion coating layer on the $\mathrm{Zn}$ substrate of the specimens prepared at $\mathrm{pH} 12.6$ and 12.9. Because the contrast of the BSE images is dependent on the layer composition, this indicates that the microstructure of the conversion coating layer is divided into two layers with different compositions when treatment is performed at or above $\mathrm{pH}$ 12.6. The areas indicated by the white boxes (1-10) on the cross sections in Fig. 9 (d) and (f) were analyzed by EDX, and the results are shown in Table 2. At $\mathrm{pH} 12.4, \mathrm{Zn}, \mathrm{Al}, \mathrm{C}$ and $\mathrm{O}$ were detected in both areas 1 and 2, indicating that the conversion coating layer consists of only $\mathrm{Zn}$ $\mathrm{Al}-\mathrm{CO}_{3} \mathrm{LDH}$. At $\mathrm{pH} 12.6$ and 12.9 , the area of medium brightness appears to consist of $\mathrm{ZnO}$; only $\mathrm{Zn}$ and $\mathrm{O}$ were detected in areas 5, 8 and 9. The $\mathrm{Zn}-\mathrm{Al}-\mathrm{CO}_{3} \mathrm{LDH}$ layer exists on the $\mathrm{ZnO}$ layer. These results are in agreement with the results obtained by XRD and, again, indicate that the conversion coating layer consists of $\mathrm{ZnO}$ as well as $\mathrm{Zn}-\mathrm{Al}-\mathrm{CO}_{3} \mathrm{LDH}$ with treatment at a $\mathrm{pH}$ at or above 12.6 (Fig. 4). As pH increases in this limited $\mathrm{pH}$ region, the $\mathrm{ZnO}$ layer tends to thicken and the $\mathrm{Zn}-\mathrm{Al}-\mathrm{CO}_{3}$ $\mathrm{LDH}$ layer tends to become thinner. In addition to the layer thickness, as mentioned before, differences in the microstructure of the conversion coating layer, such as the density and uniformity of the $\mathrm{LDH}$, along with the fraction of $\mathrm{ZnO}$ to $\mathrm{LDH}$, could also affect corrosion resistance.

\subsection{Effect of Initial Formation of ZnO on LDH Crystal Growth}

The stability diagram of $\mathrm{Zn}$ indicates that aqueous $\mathrm{Zn}(\mathrm{OH})_{3}^{-}$ is stable in the $\mathrm{pH}$ range from 11.5 to 13.3 and, in addition, solid $\mathrm{ZnO}$ can precipitate if the concentration of $\mathrm{Zn}(\mathrm{OH})_{3}^{-}$is above saturation, indicating a dependence on the concentration of $\mathrm{Zn}(\mathrm{OH})_{3}^{-}$(Ref 22). From the stability diagram of $\mathrm{Al}$, aqueous $\mathrm{Al}(\mathrm{OH})_{4}^{-}$is stable in this $\mathrm{pH}$ range (Ref 22). As mentioned above, $\mathrm{Zn}^{2+}$ could be provided by the dissolution reaction of the $\mathrm{Zn}$ substrate and $\mathrm{CO}_{3}{ }^{2-}$ can be provided by the dissolution of $\mathrm{CO}_{2}$ from air. Therefore, it is reasonable to assume that the following chemical reactions could occur at the lower end of this $\mathrm{pH}$ range, resulting in the formation of $\mathrm{Zn}-\mathrm{Al}-\mathrm{CO}_{3} \mathrm{LDH}$ :

$$
\begin{aligned}
& 2 \mathrm{Zn}(\mathrm{s})+\mathrm{O}_{2}+2 \mathrm{H}_{2} \mathrm{O}+(\mathrm{OH})^{-} \rightarrow 2 \mathrm{Zn}(\mathrm{OH})_{3}^{-} \\
& \mathrm{CO}_{2}(\mathrm{~g})+2\left(\mathrm{OH}^{-}\right) \rightarrow \mathrm{CO}_{3}^{2-}+\mathrm{H}_{2} \mathrm{O} \\
& \mathrm{Al}(\mathrm{OH})_{4}^{-}+2 \mathrm{Zn}(\mathrm{OH})_{3}^{-}+0.5 \mathrm{CO}_{3}^{2-}+\mathrm{xH}_{2} \mathrm{O} \\
& \quad \rightarrow \mathrm{Zn}_{2} \mathrm{Al}(\mathrm{OH})_{6}\left(\mathrm{CO}_{3}\right)_{0.5} \cdot \mathrm{xH}_{2} \mathrm{O} \downarrow \\
& \quad(\mathrm{s})\left(\mathrm{Zn}-\mathrm{Al}-\mathrm{CO}_{3} \mathrm{LDH}\right)+4 \mathrm{OH}^{-}
\end{aligned}
$$

However, at the high end of this $\mathrm{pH}$ range, the concentration of $\mathrm{Zn}(\mathrm{OH})_{3}^{-}$would be expected to be much higher than that at the lower end of the $\mathrm{pH}$ range. This should occur because the rate of the dissolution reaction of $\mathrm{Zn}$, Reaction (1), will be accelerated in the solution at the interface with the EG steel surface (Fig. 10). At the high end of the $\mathrm{pH}$ range, the dissolution reaction of $\mathrm{Zn}$ can be divided into the following two reactions:

$$
\begin{aligned}
& \mathrm{Zn}(\mathrm{s})+2\left(\mathrm{OH}^{-}\right) \rightarrow \mathrm{ZnO}(\mathrm{s})+\mathrm{H}_{2} \mathrm{O}+2 \mathrm{e}^{-} \\
& \mathrm{ZnO}(\mathrm{s})+\mathrm{H}_{2} \mathrm{O}+\mathrm{OH}^{-} \rightarrow \mathrm{Zn}(\mathrm{OH})_{3}^{-}
\end{aligned}
$$

The formation of $\mathrm{Zn}-\mathrm{Al}-\mathrm{CO}_{3} \mathrm{LDH}$ at the interface of $\mathrm{ZnO}$ and the solution (rather than on the bare $\mathrm{Zn}$ surface) in the higher $\mathrm{pH}$ region could affect the microstructure of the $\mathrm{LDH}$ layer. The initial formation of $\mathrm{ZnO}$ could work as a surface conditioner and could make the LDH crystals finer, denser and more uniform. 


\subsection{Effect of Microstructure of Conversion Coating Layer on Corrosion Resistance}

The changes in the microstructure of the conversion coating layer are summarized in Fig. 11 as schematic images. When the solution $\mathrm{pH}$ is below 12.6, cracks and crevices are introduced into the LDH crystals because the LDH crystals form directly on the EG steel surface. This could cause lower corrosion resistance because electrolytes can reach the $\mathrm{Zn}$ substrate through cracks and crevices, although corrosion resistance did increase as the layer thickness increased. When the solution $\mathrm{pH}$ is around 12.6, higher corrosion resistance is observed in spite of the thinner layer. This is attributed to the presence of the layer of initially formed $\mathrm{ZnO}$, which appears to result in the formation of finer $\mathrm{LDH}$ crystals that are denser and more uniform. Additionally, when the solution $\mathrm{pH}$ exceeds 12.6, the ratio of $\mathrm{ZnO}$ to $\mathrm{LDH}$ in the coating increases and this, in turn, could result in lower corrosion resistance because $\mathrm{ZnO}$ is not protective due to its high solubility in the $\mathrm{NaCl}$ solution.

\section{Conclusions}

The effect of solution $\mathrm{pH}$ on $\mathrm{LDH}$ formation on $\mathrm{EG}$ steel sheets was investigated, and the following conclusions were reached:

(1) Carbonate was determined to be the interlayer anion formed in $\mathrm{LDH}$ crystals created by the procedure discussed in this paper. $\mathrm{Zn}_{2} \mathrm{Al}(\mathrm{OH})_{6}\left(\mathrm{CO}_{3}\right)_{0.5} \cdot \mathrm{xH}_{2} \mathrm{O}$ (an $\mathrm{LDH})$ readily forms on $\mathrm{EG}$ steel surfaces when the surfaces are immersed in the $\mathrm{Na}_{2} \mathrm{Al}_{2} \mathrm{O}_{4}$-based solution.

(2) The corrosion resistance observed in association with the above-discussed LDH coating increases with increasing solution $\mathrm{pH}$ up to $\mathrm{pH}$ 12.6. Above $\mathrm{pH}$ 12.6, however, a sharp decrease in corrosion resistance was observed. This trend of corrosion resistance can be explained in some respects by the conversion coating layer thickness.

(3) However, for samples treated at $\mathrm{pH}$ 12.6, the initial formation of $\mathrm{ZnO}$ results in the formation of a more uniform and protective LDH layer, resulting in higher corrosion resistance in spite of a thinner layer.

\section{Acknowledgments}

The authors wish to thank Prof. Belinda Hurley and Prof. Gerald S. Frankel (The Ohio State University, USA) for their discussions of this paper and help with grammatical editing. They also wish to acknowledge the financial support of JFE Steel Corporation, Japan.

\section{Open Access}

This article is distributed under the terms of the Creative Commons Attribution 4.0 International License (http://creativecommons.org/ licenses/by/4.0/), which permits unrestricted use, distribution, and reproduction in any medium, provided you give appropriate credit to the original author(s) and the source, provide a link to the Creative Commons license, and indicate if changes were made.

\section{References}

1. R.G. Buchheit, H. Guan, S. Mahajanam, and F. Wong, Active Corrosion Protection and Corrosion Sensing in Chromate-Free Organic Coatings, Prog. Org. Coat., 2003, 47, p 174-182, https://doi.org/10. 1016/j.progcoat.2003.08.003

2. P.S.V. Maharajanam and R.G. Buchheit, Characterization of $\mathrm{Zn}-\mathrm{Al}-$ $\mathrm{V}_{10} \mathrm{O}_{28}{ }^{6-}$ Corrosion-Inhibiting Hydrotalcite Pigments in Epoxy Resins. Electrochemical Society Proceedings, Vol. 2003-23 (2003)

3. S. Chrisanti, S. Mahajanam and R.G. Buchheit, The Use of Ion Exchange Compounds as Corrosion Inhibiting and Sensing Pigments in Organic Coatings. Proceedings of 3rd International Surface Engineering Congress, August 2-4, 2004, Orlando Airport Marriot, Orlando, Florida, USA (2004)

4. S.P.V. Maharajanam and R.G. Buchheit, Characterization of Inhibitor Release from $\mathrm{Zn}-\mathrm{Al}-\left[\mathrm{V}_{10} \mathrm{O}_{28}\right]^{6-}$ Hydrotalcite Pigments and Corrosion Protection from Hydrotalcite-Pigmented Epoxy Coatings, CORROSION, 2008, 69(3), p 230-240, https://doi.org/10 $.5006 / 1.3278468$

5. G. Williams and H.N. McMurry, Anion-Exchange Inhibition of Filiform Corrosion on Organic Coated AA2024-T3 Aluminum Alloy by Hydrotalcite-Like Pigment, Electrochem. Solid-State Lett., 2003, 6(3), p B9-B11, https://doi.org/10.1149/1.1539771

6. G. Williams and H.N. McMurry, Inhibition of Filiform Corrosion on Polymer Coated AA2024-T3 by Hydrotalcite-Like Pigments Incorporating Organic Anions, Electrochem. Solid-State Lett., 2003, 7(5), p B13-B15, https://doi.org/10.1149/1.1691529

7. H.N. McMurry and G. Williams, Inhibition of Filiform Corrosion on Organic-Coated Aluminum Alloy by Hydrotalcite-Like Anion-Exchange Pigments, CORROSION, 2004, 60(3), p 219-228, https://doi. org $/ 10.5006 / 1.3287724$

8. A.J. Coleman, H.N. McMurray, G. Williams, A. Afseth, and G. Scanmans, Filiform Corrosion on 6000 Series Aluminum: Kinetics and Inhibition, Mater. Sci. Forum, 2006, 519-521, p 629-634, https://doi. org/10.4028/www.scientific.net/MSF.519-521.629

9. G. Williams, Critical Factors in the Inhibition of Filiform Corrosion by In-coating Ion-Exchange Pigments, ECS Trans., 2010, 24(1), p 67-76, https://doi.org/10.1149/1.3453607

10. G. Williams and H.N. McMurry, Inhibition of Filiform Corrosion on Organic-Coated AA2024-T3 by Smart-Release Cation and AnionExchange Pigments, Electrochim. Acta, 2012, 69, p 287-294, https://d oi.org/10.1016/j.electacta.2012.03.002

11. G. Williams, S. Greary, M. Loveridge, and H.N. McMurray, SmartRelease Inhibition of Corrosion-Driven Organic Coating Delamination on Galvanized Steel Surface, ECS Trans., 2012, 41(15), p 93-103, h ttps://doi.org/10.1149/1.3696872

12. Y. Dong, F. Wang, and Q. Zhou, Protective Behaviors of 2Mercaptobenzothiazole Intercalated Zn-Al-Layered Double Hydroxide Coating, J. Coat. Technol. Res., 2014, 11(5), p 793-803, https://doi.org/ 10.1007/s11998-014-9568-9

13. M.L. Zheludkevich, S.K. Poznyak, L.M. Rodrigues, D. Raps, L.F. Dick, T. Nunes, and M.G.S. Ferreira, Active Protection Coatings with Layered Double Hydroxide Nanocontainers of Corrosion Inhibitor, Corros. Sci., 2010, 52, p 602-611, https://doi.org/10.1016/j.corsci.200 9.10.020

14. J. Tedim, A. Kuznetsova, A.N. Salak, F. Montemor, D. Snihirova, M. Pilz, M.L. Zheludkevich, and M.G.S. Ferreira, Zn-Al Layered Double Hydroxides as Chloride Nanotraps in Active Protective Coatings, Corros. Sci., 2012, 55, p 1-4, https://doi.org/10.1016/j.corsci.2011.10. 003

15. R.G. Buchheit, C.A. Drewien, J.L. Finch, and G.E. Stoner, Nonchromate Talc Conversion Coatings for Aluminum. CORROSION 94, Paper No. 542, (1994)

16. R.G. Buchheit, M.D. Bode, and G.E. Stoner, Corrosion-Resistance, Chromate-Free Talc Coatings for Aluminum, Corrosion, 1994, 50(3), p 205-214, https://doi.org/10.5006/1.3293512

17. R.G. Buchheit, Alkaline Oxide Conversion Coatings for Aluminum Alloys. CORROSION 96, Paper No. 625, (1996), 625/1-625/14

18. W. Zhang, and R.G. Buchheit, Hydrotalcite Coating Formation on Al$\mathrm{Cu}-\mathrm{Mg}$ Alloys from Oxidizing Bath Chemistries, Corrosion, 2002, 58(7), p 591-600, https://doi.org/10.5006/1.3277650

19. R.G. Buchheit, and H. Guan, Formation and Characteristics of Al-Zn Hydrotalcite Coatings on Galvanized Steel, JCT Res., 2004, 1(4), p 277-290, https://doi.org/10.1007/s11998-004-0030-2 
20. S.S. Hayrapetyan, L.G. Mangasaryan, M.R. Tovmasyan, and H.G. Khachatryan, Precipitation of Aluminum Hydroxide from Sodium Aluminate, by Treatment with Formalin, and Preparation of Aluminum Oxide, Acta Cromatogr., 2006, 16, p 192-203

21. X. Xue, Q. Gu, G. Pan, J. Liang, G. Hyang, G. Sun, S. Ma, and X. Yang, Nanocage Structure Derived from Sulfonated B-cyclodextrin Intercalated Layered Double Hydroxides and Selective Adsorption For Phenol Compounds, Inorg. Chem., 2014, 53, p 1521-1529, https://doi. org/10.1021/ic402494m
22. M. Pourbaix, Atlas of electrochemical equilibria in aqueous solutions, NACE, Houston (1974) 406-413 and 168-176

Publisher's Note Springer Nature remains neutral with regard to jurisdictional claims in published maps and institutional affiliations. 